\title{
Geology
}

\section{Sub-decadal turbidite frequency during the early Holocene: Eel Fan, offshore northern California}

Charles K. Paull, Mary McGann, Esther J. Sumner, Philip M. Barnes, Eve M. Lundsten, Krystle Anderson, Roberto Gwiazda, Brian Edwards and David W. Caress

Geology published online 15 August 2014; doi: 10.1130/G35768.1

\section{Email alerting services}

\section{Subscribe}

Permission request click www.gsapubs.org/cgi/alerts to receive free e-mail alerts when new articles cite this article

click www.gsapubs.org/subscriptions/ to subscribe to Geology

click http://www.geosociety.org/pubs/copyrt.htm\#gsa to contact GSA

Copyright not claimed on content prepared wholly by U.S. government employees within scope of their employment. Individual scientists are hereby granted permission, without fees or further requests to GSA, to use a single figure, a single table, and/or a brief paragraph of text in subsequent works and to make unlimited copies of items in GSA's journals for noncommercial use in classrooms to further education and science. This file may not be posted to any Web site, but authors may post the abstracts only of their articles on their own or their organization's Web site providing the posting includes a reference to the article's full citation. GSA provides this and other forums for the presentation of diverse opinions and positions by scientists worldwide, regardless of their race, citizenship, gender, religion, or political viewpoint. Opinions presented in this publication do not reflect official positions of the Society.

\section{Notes}

Advance online articles have been peer reviewed and accepted for publication but have not yet appeared in the paper journal (edited, typeset versions may be posted when available prior to final publication). Advance online articles are citable and establish publication priority; they are indexed by GeoRef from initial publication. Citations to Advance online articles must include the digital object identifier (DOIs) and date of initial publication.

(C) Geological Society of America

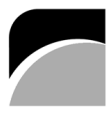

THE GEOLOGICAL SOCIETY OF AMERICA 


\title{
Sub-decadal turbidite frequency during the early Holocene: Eel Fan,
} offshore northern California

\author{
Charles K. Paull1', Mary McGann², Esther J. Sumner ${ }^{1}$, Philip M. Barnes ${ }^{3}$, Eve M. Lundsten', Krystle Anderson', \\ Roberto Gwiazda ${ }^{1}$, Brian Edwards ${ }^{2}$, and David W. Caress ${ }^{1}$ \\ ${ }^{1}$ Monterey Bay Aquarium Research Institute, Moss Landing, California 95039, USA \\ ${ }^{2}$ U.S. Geological Survey, Pacific Coastal and Marine Science Center, Menlo Park, California 94025, USA \\ ${ }^{3}$ National Institute of Water \& Atmospheric Research, Wellington 6241, New Zealand
}

\begin{abstract}
Remotely operated and autonomous underwater vehicle technologies were used to image and sample exceptional deep sea outcrops where an $\sim 100-$ m-thick section of turbidite beds is exposed on the headwalls of two giant submarine scours on Eel submarine fan, offshore northern California (USA). These outcrops provide a rare opportunity to connect young deep-sea turbidites with their feeder system. ${ }^{14} \mathrm{C}$ measurements reveal that from 12.8 ka to $7.9 \mathrm{ka}$, one turbidite was being emplaced on average every $7 \mathrm{yr}$. This emplacement rate is two to three orders of magnitude higher than observed for turbidites elsewhere along the Pacific margin of North America. The turbidites contain abundant wood and shallow-dwelling foraminifera, demonstrating an efficient connection between the Eel River source and the Eel Fan sink. Turbidite recurrence intervals diminish fivefold to $\sim 36 \mathrm{yr}$ from $7.9 \mathrm{ka}$ onward, reflecting sea-level rise and re-routing of Eel River sediments.
\end{abstract}

\section{INTRODUCTION}

Movement of sediment from terrestrial sources onto deep-sea fans is a fundamental step in global sediment cycles (e.g., Piper and Normark, 2009). Flooding rivers, particularly those draining mountainous terrain, can carry massive amounts of sediment and generate hyperpycnal flows when discharging waters arrive at the ocean (Mulder and Syvitski, 1995). Sediments carried in flooding events are either deposited on the shelf and upper slope or continue downslope and pass directly into the deep sea, particularly if they achieve hyperpycnal densities and are captured within a submarine canyon.

Submarine canyons are major conduits that funnel sediments from continental shelves out onto deep-sea fans. Submarine gravity flows are the primary transport mechanism to move sediments through submarine canyons (e.g., Puig, et al., 2013). They occur as discrete energetic events and commonly leave distinctive deposits of varying thickness. Although the deposits are laid down in a geologic instant, centennial recurrence intervals are the norm along the Pacific margin (Table DR1 in the GSA Data Repository $^{1}$ ) and are common in other areas (e.g., Sumner et al., 2013, their Item DR1 in GSA Data Repository 2013212). Trigger mechanisms for flows in submarine canyons include seismic shaking during earthquakes, wave loading elevating pore-water pressure in sediments during storms, failure of oversteepened slopes such as delta foresets, as well as hyperpycnal

${ }^{1}$ GSA Data Repository item 2014303, supplementary tables with turbidite recurrence intervals and ${ }^{14} \mathrm{C}$ data, is available online at www.geosociety.org/pubs /ft2014.htm, or on request from editing @ geosociety .org or Documents Secretary, GSA, P.O. Box 9140, Boulder, CO 80301, USA. flows from flooding rivers (e.g., Piper and Normark, 2009; Talling, 2014). There is a limited understanding of how frequently these events occur and the importance of direct connections between sediment sources and sinks.

The present-day Eel River, off northern California (USA), periodically experiences extreme flooding events with the capacity to generate hyperpycnal flows (Mulder and Syvitski, 1995). The fate of recent sediment discharges from Eel River has been studied intensively, in part through the landmark STRATAFORM Project (Strata Formation on Margins; e.g., Nittrouer, 1999; Warrick, 2014, and references therein), which was ostensibly looking at source-to-sink sediment transport, but stopped at the shelf edge.

Eel Canyon lies offshore of the mouth of Eel River (Fig. 1) with the river and canyon presently disconnected by a $12-\mathrm{km}$-wide shelf. Sediment from recent Eel River floods is not

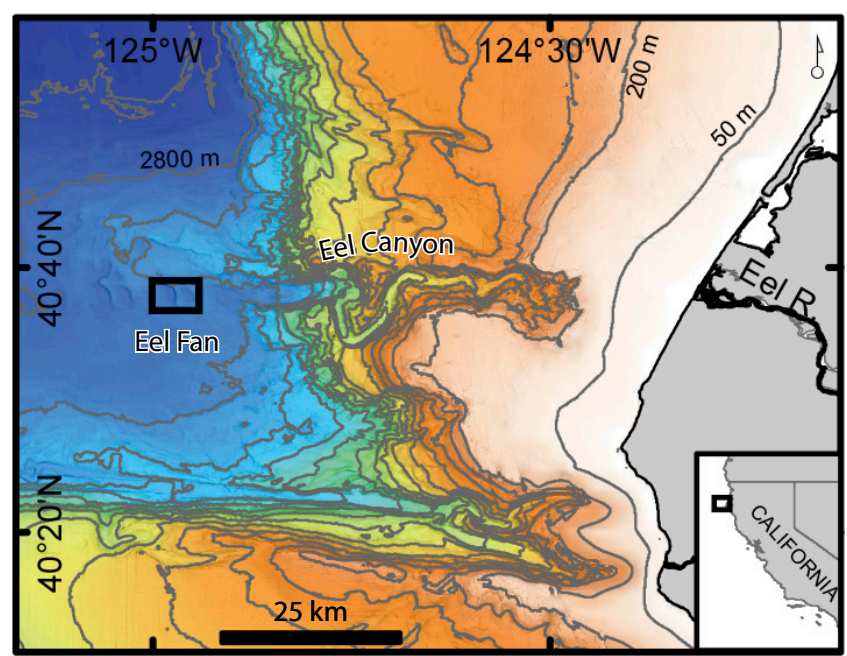

primarily funneled directly into Eel Canyon (Warrick, 2014), but instead is temporarily deposited on the shelf and upper slope until resuspended by waves (Puig et al., 2004). However, when sea level was lower in the Pleistocene and early Holocene, the Eel River was directly connected with the Eel Canyon, which presumably captured flows emanating from Eel River (Burger et al., 2001). The effect of a direct connection between the Eel River sediment source, presumably via Eel Canyon, to the Eel Fan sediment sink has not been investigated previously.

Here we report on an $\sim 100$-m-thick stratigraphic sequence of uppermost Pleistocene and lower Holocene strata exposed by giant submarine scours cut into the Eel Fan directly downstream of Eel Canyon. The exposed stratigraphic sequence consists of rapidly deposited turbidites that provide insight into the river-tofan connectivity over the Holocene transgression of sea level.

\section{METHODS}

Detailed seafloor surveys of two giant scours were conducted (Figs. 1 and 2) using an autonomous underwater vehicle (AUV; Caress et al., 2008) developed at the Monterey Bay Aquarium Research Institute (MBARI). Two dives in A.D. 2011 produced a 1-m-resolution bathymetric grid of a $4.8 \mathrm{~km} \times 3.9 \mathrm{~km}$ area. The surveys provided a context for seafloor observation and sampling transects conducted in 2011 and
Figure 1. Map showing location of high-resolution bathymetric surveys (box) shown in Figure 2 with respect to Eel Canyon and Eel River, California, USA. Box in inset shows location of main figure with respect to California. Contours are at $50 \mathrm{~m}$, and every $200 \mathrm{~m}$ interval. R.-River. 


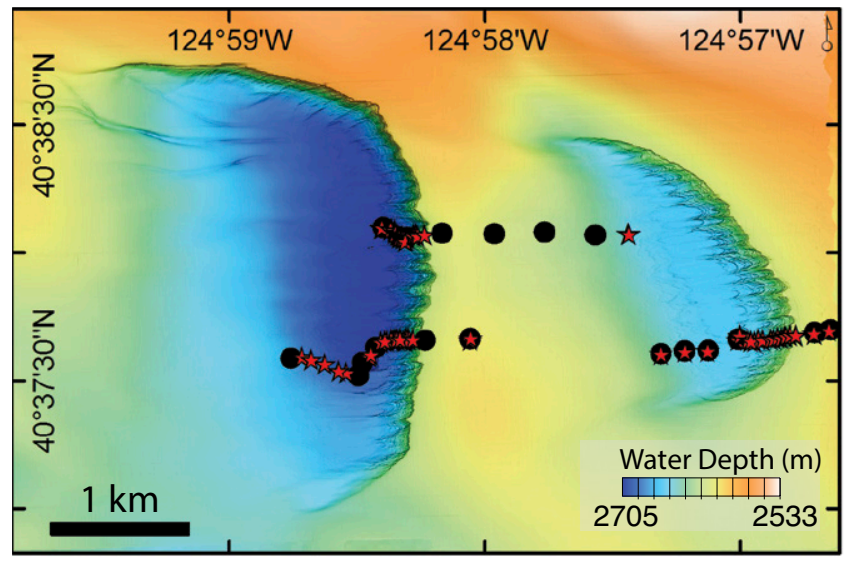

2013 using MBARI's remotely operated vehicle (ROV) Doc Ricketts.

High-definition video and samples were collected on ROV dive transects that crossed the steep eastern flank of both scours (Figs. 2 and 3). Sediment samples were collected using the ROV's mechanical arm by inserting push cores horizontally into the face of exposed beds (Fig. $3 \mathrm{~A})$. Push core samples were taken at a nominal vertical depth spacing of $5 \mathrm{~m}$ on each dive transect. Samples of wood were also pulled directly out from exposed beds. Eighteen (18) vibracores, up to $134 \mathrm{~cm}$ in length, were collected with the ROV (e.g., Paull et al., 2013).

The number of beds exposed on the face of both scours was estimated using segments of the ROV video where clear, well-lit video of the scarp face exists. Beds were counted using a fixed laser beam as the ROV moved up or down outcrops. The start and end depths of the video transect segments were determined using a precision depth sensor on the ROV. Average bed thickness was also measured from visual core logs of the vertical vibracores.

Radiocarbon measurements were made on 48 samples (Table DR2). Sixteen (16) samples of woody material were obtained directly from exposed beds using the ROV's mechanical arm (Fig. 3A), from surfaces of split cores, or from the $>63 \mu \mathrm{m}$ washed fraction. Thirty two (32) samples of mixed benthic foraminifera were handpicked from the $>63 \mu \mathrm{m}$ fraction of sediment from push cores and vibracores.

\section{RESULTS}

The two giant scours are on Eel Fan $20 \mathrm{~km}$ west of the mouth of Eel Canyon (Fig. 1). The seafloor surrounding these scours is in $\sim 2.6 \mathrm{~km}$ water depth. The scours are as much as $3.5 \mathrm{~km}$ across in the north-south direction, distinctly asymmetrical in shape with semi-circular headwall scarps on their eastern sides, and with vertical reliefs of $100 \mathrm{~m}$ and $56 \mathrm{~m}$. Other similar-size scours occur on Eel Fan and on the flanks of Eel Canyon (Lamb et al., 2008).

The 1-m-resolution bathymetric grids (Fig. 2) show that the eastern flanks have sustained average slopes of $\geq 30^{\circ}$. The steep eastern flanks are divided into 50-150-m-wide scalloped-shaped embayments, with horizontal bedding planes cropping out uninterrupted along the faces of the scours (Fig. 3B).

Visual observations during ROV dive transects up the eastern flanks of these scours (Fig.
2) show repetitive sequences consisting of horizontal beds exposed by the scours (Figs. 3A and $3 \mathrm{~B}$ ). The beds consist of 1-25-cm-thick recessed layers composed of fine sand overlain by $1-15-\mathrm{cm}$-thick layers composed of finegrained sediment with fresh smooth faces that stand proud from the outcrop face, suggesting that they are more cohesive (Paull et al., 2013). The basal contacts of sand layers are sharp. Horizons containing concentrated twigs and branches are common within the sandy layers, and an occasional log was seen.

Vibracores show beds with sharp basal contacts followed by fining-upward intervals composed of fine sand grading to silty mud above (Fig. 3C). Clumps of woody materials coming from madrone (Arbutus menziesii) and conifer trees commonly form horizons within the sandy units. The cumulative $13.26 \mathrm{~m}$ core length obtained from 18 vibracores contains 161 complete turbidite beds with a mean bed thickness of $8 \pm 6 \mathrm{~cm}$ $(1 \sigma)$ and a maximum thickness of $32 \mathrm{~cm}$.

The average thickness of the beds was also determined from ROV videotapes. A total of 2020 fining-up beds were counted in the best video footage from all three sampling transects, which covered $225.6 \mathrm{~m}$ of vertical section. This indicates that the average thickness of the beds exposed on the face of the giant scours is $11 \mathrm{~cm}$. While average bed thicknesses estimated from video footage $(11 \mathrm{~cm})$ and from bed counting in vibracores $(8 \mathrm{~cm})$ are similar, the more conservative estimate of $11 \mathrm{~cm}$ is used in subsequent calculations.

Fine-grained materials at the top of beds were initially targeted for ${ }^{14} \mathrm{C}$ measurements, anticipating that they would be hemipelagic in origin and contain planktonic foraminifera. However, fine-grained sediments were found to be barren of foraminifera. Subsequently, foraminifera from coarser-grained intervals were sampled with the knowledge that they had been transported from shallower depth. Although
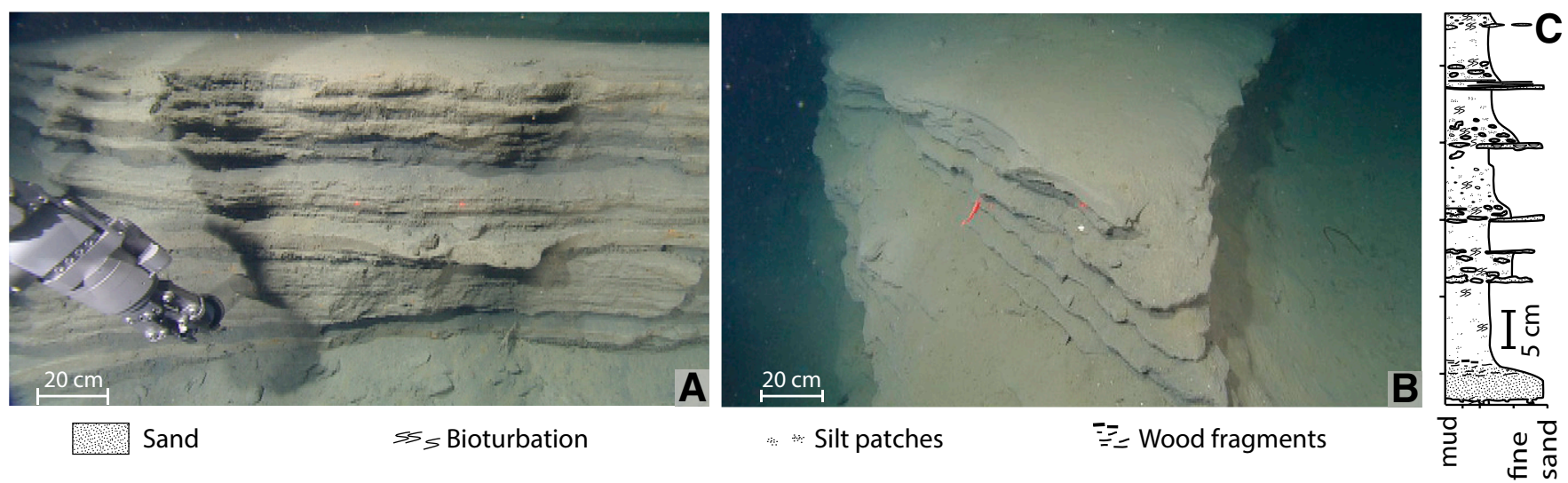

Figure 3. A,B: Video still images with an $\sim 2.5 \mathrm{~m}$ field of view showing turbidite beds in scours on Eel Fan, California, USA. Horizontal push core being taken from the outcrop face is shown in A. Note beds wrap around V-shaped ridge in B. C: Lithologic drawing illustrating a typical $60-\mathrm{cm}$-high sequence of beds recovered in a vibracore from the Eel scours. Note the horizontal scale indicates grain size, not morphology, and that the weathering profile is reverse (i.e., fine sand is recessed). 
planktonic foraminifera were still uncommon in coarser-grained layers, these sediments yielded plentiful benthic foraminifera dominated by taxa characteristic of shelf and slope environments, as well as specimens indicative of marsh environments. Twenty-six (26) samples of mixed benthic foraminifera, obtained from water depths between $2620 \mathrm{~m}$ and $2707 \mathrm{~m}$, were specifically picked to contain only bathyal species and yielded corrected ages that ranged from $6.1 \mathrm{kyr}$ B.P. to $21.9 \mathrm{kyr}$ B.P. The pattern of age versus depth is similar in both scours (Fig. 4).

${ }^{14} \mathrm{C}$ measurements made on wood and/or woody materials collected from outcrops in the larger scour yielded a linear correlation $\left(\mathrm{r}^{2}=0.81\right)$ between age and water depth from $2631 \mathrm{~m}$ to $2707 \mathrm{~m}$ (Fig. 4). This linear relationship indicates that the lower $76 \mathrm{~m}$ of this section was emplaced in only 4.9 k.y., spanning an age range of 12.8-7.9 kyr B.P., and yielding an average accumulation rate of $1.6 \mathrm{~cm} / \mathrm{yr}$. Given an average bed thickness of $11 \mathrm{~cm}$, this 76-m-thick section has $\sim 690$ beds, which yields a minimum turbidite recurrence interval of $\sim 7$ yr. While no wood samples were recovered from beds younger than $7.9 \mathrm{kyr}$ B.P., the slope of the ${ }^{14} \mathrm{C}$-dated foraminifera ages versus depth profile declines after 7.9 kyr B.P. and projects to young ages near the seafloor (Fig. 4).

An exceptional sequence of beds are exposed on the eastern face of 100 -m-deep giant scours cut into the surface of Eel Fan. Robotic vehicles have enabled outcrop studies of the 100-m-thick deep-sea stratigraphic sequence otherwise unobtainable without a drill ship.

\section{DISCUSSION}

Given its location (Fig. 1), this stratigraphic section is an obvious sink for Eel River sediments, and provides a rare opportunity to connect deepsea deposits with their feeder systems.

Cores and ROV observations show that the beds are mostly normally graded (Fig. 3C). The abundance of shallow-water foraminifera and wood in these beds indicates shallow-water sources and rapid inclusion of terrestrial material (Liu et al., 2012). Inverse grading at bed bases, which some authors suggest is characteristic of hyperpycnal flows (e.g., Mulder et al., 2003), is rarely observed in these deposits. However, inverse grading as a diagnostic criterion for hyperpycnal flows has been questioned (Lamb and Mohrig, 2009; Talling, 2014). These beds are interpreted to be turbidites whose origin is closely connected to discharge from Eel River.

${ }^{14} \mathrm{C}$ ages of woody material indicate that all the exposed turbidite beds were deposited within the past 12.9 k.y. Depth-versus-age profiles of foraminifera match the pattern of woody material but with a general offset toward older ages, which is consistent with the material having been reworked (Fig. 4).

The absence of identifiable planktonic foraminifera-bearing hemipelagic sediments separating subsequent turbidite beds is an independent confirmation that these turbidites were deposited rapidly. Hemipelagic sediment accumulations would be minimal in comparison with sediment deposition from turbidites with a sub-decadal recurrence frequency.

Diminished sediment accumulation rates occurred in the late Holocene, as the remaining $\sim 24 \mathrm{~m}$ of exposed section accumulated in 7.9 k.y. The average accumulation rate over this
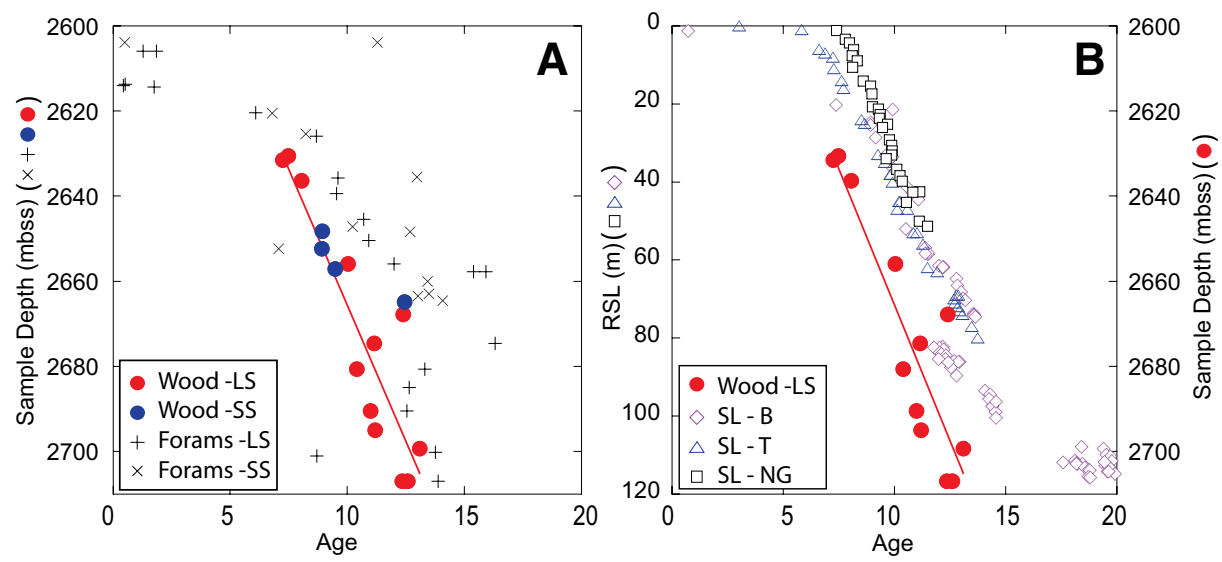

Figure 4. A: ${ }^{14} \mathrm{C}$ age (in kyr B.P.) versus depth (in meters below sea surface, mbss) of material sampled from turbidite beds exposed by giant scours on Eel Fan, California, USA. Filled circles show measurements on woody material (red-large scour [LS]; blue-small scour [SS]). Calibrated age measurements made on benthic foraminifera from the large $(+)$ and small $(x)$ scours are shown. Red line is linear fit to ${ }^{14} \mathrm{C}$ age measurements made on woody material from large scour. B: Repeat measurements on woody material from large scour including data on relative sea-level (RSL) positions in meters (after Smith et al., 2011, their figure 4A) in Barbados (SL-B), Tahiti (SL-T), and Papua New Guinea (SL-NG) at the time of turbidite deposition. Note that the $7 \mathrm{yr}$ turbidite recurrence interval occurs during lower relative sea level when the Eel shelf was exposed, and shifts as the present sea-level highstand is approached (RSL $=0 \mathrm{~m}$ ). Core locations and ${ }^{14} \mathrm{C}$ data are provided in Table DR2 (see footnote 1). interval is $0.3 \mathrm{~cm} / \mathrm{yr}$, which is substantially less than earlier in the Holocene $(\sim 1.6 \mathrm{~cm} / \mathrm{yr})$. Using an average bed thicknesses of $11 \mathrm{~cm}$ indicates that the turbidite recurrence interval in the late Holocene was $36 \mathrm{yr}$. This rate is similar to previously reported late Holocene deep-sea turbidite recurrence intervals measured $32 \mathrm{~km}$ to the south in the Mendocino channel system (34 yr) and $35 \mathrm{~km}$ to the west of the Eel scours on more distal parts of Eel Fan (e.g., 60 yr.; Goldfinger et al., 2012; Fig. 1).

The turbidite recurrence interval of $7 \mathrm{yr}$, which was sustained for at least a 4.9 k.y. period during the deglaciation and early Holocene, is distinctly shorter than the late Holocene turbidite recurrence interval, and unique along the Pacific margin of North America (Table DR1). At issue is what conditions resulted in this short deep-sea-fan turbidite recurrence interval and the change in its frequency at ca. 7.9 kyr B.P.

The $7 \mathrm{yr}$ turbidite recurrence interval measured on Eel Fan is nearly two orders of magnitude shorter than the estimated recurrence interval of mega-earthquakes along most of the Cascadia margin (Goldfinger et al., 2012) and observed on deep-sea fans and basin floors elsewhere (Table DR1). To attribute these frequent turbidite events primarily to earthquake triggering would require a distinct local change in earthquake frequency at ca. $7.9 \mathrm{kyr}$ B.P., for which there is no evidence (Atwater et al., 2003).

Historical records indicate that decadal flooding from the Eel River events since A.D. 1954 have left identifiable deposits within upper Eel Canyon (e.g., Mullenbach and Nittrouer, 2006), and that floods large enough to generate hyperpycnal flows occur at a recurrence interval similar to that of late Holocene turbidites (e.g., Warrick, 2014). The observed turbidite beds may have originated as hyperpycnal flows triggered by direct river discharge into the canyon head (e.g., Mulder and Syvitski, 1995), or have been generated by frequent collapse of rapidly accumulating sediment near the canyon head during or following river flooding events (Carter et al. 2012; Talling, 2014), or by storm wave loading (Puig et al., 2004).

Currently, much of the sediment discharged from Eel River is transported along the shelf, and is partly deposited beyond the slope and partly dispersed to the open ocean, as shown by the STRATAFORM project (e.g., Nittrouer, 1999; Warrick, 2014, and references therein). The period of rapid sediment accumulation and $7 \mathrm{yr}$ turbidite recurrence on Eel Fan prior to ca. $7.9 \mathrm{kyr}$ B.P. corresponds with a period of lower sea level, when the continental shelf off Eel River was sufficiently shallow to allow sediments from Eel River to enter directly into Eel Canyon (Burger et al., 2001). During this period, the role of the canyon as a sediment transport conduit was enhanced and sediments moved from the river source to the sink on the 
fan more efficiently. The decrease in turbidite frequency in the late Holocene is concurrent with the transgression of the Eel shelf at $7.9 \mathrm{kyr}$. B.P. (Fig. 4) and the inevitable loss of the direct connection between Eel River and Eel Canyon.

The extraordinary exposure of a deep-sea turbidite sequence found in the Eel Fan scours reveals the impact of focused sediment delivery. While salient features of this sequence are found elsewhere (e.g., the high recurrence, a direct river-fed fan connection [e.g., Mulder et al., 2001], and high-resolution records [e.g., Romans et al., 2009]; this location is unique because all features are present in this single setting.

\section{SUMMARY AND CONCLUSIONS}

An 100-m-thick sequence of late Pleistocene and Holocene-age turbidite beds is exposed on the flanks of two giant scours on Eel Fan downstream from Eel Canyon and Eel River. ${ }^{14} \mathrm{C}$ measurements indicate that the turbidite recurrence interval was only $7 \mathrm{yr}$ from $12.8 \mathrm{kyr}$ B.P. to $7.9 \mathrm{kyr}$ B.P. The corresponding frequency of events greatly exceeds the regional mega-earthquake recurrence frequency. Although the beds do not indicate deposition directly from hyperpycnal flows, the abundance of woody material implies a connection to Eel River flooding events. The frequent turbidite recurrence and high accumulation rates sustained throughout the early Holocene suggest focused sediment delivery to Eel Fan. The turbidite recurrence interval of $36 \mathrm{yr}$ in the late Holocene represents a fivefold reduction in the event frequency, and is coincident with the rise in sea level isolating the head of Eel Canyon from Eel River. This not only highlights the importance of eustatic sea-level changes and submarine canyons on sediment routing from the continent to the deep sea, but also represents a rare case in which the impacts of sea-level rise and sediment re-routing on canyon sedimentation processes can be quantified with precision.

\section{ACKNOWLEDGMENTS}

The David and Lucile Packard Foundation provided support. Barnes was supported by New Zealand Royal Society International Mobility Fund grant IMF11A-63 and National Institute of Water and Atmospheric Research Core Funding. Richard Dodd of the University of California-Berkeley identified pieces of wood. We thank Katherine Coble, David Piper, Brian Romans, Jon Warrick, and two anonymous reviewers.

\section{REFERENCES CITED}

Atwater, B.F., Tuttle, M.P., Schweig, E.S., Rubin, C.M., Yamaguchi, D.K., and Hemphill-Haley, E., 2003, Earthquake recurrence inferred from paleoseismology: Developments in Quaternary Sciences, v. 1, p. 331-350, doi:10.1016/S1571 -0866(03)01015-7.

Burger, R.L., Fulthorpe, C.S., and Austin, J.A., Jr., 2001, Late Pleistocene channel incisions in the southern Eel River Basin, northern California: Implications for tectonic vs. eustatic influences on shelf sedimentation patterns: Marine Geology, v. 177 , p. $317-330$, doi:10.1016/S0025 $-3227(01) 00166-9$.

Caress, D.W., Thomas, H., Kirkwood, W.J., McEwen, R., Henthorn, R., Clague, D.A., Paull, C.K., Paduan, J., and Maier, K.L., 2008, High-resolution multibeam, sidescan, and subbottom surveys using the MBARI AUV D. Allan B., in Reynolds, J.R., and Greene, H.G., eds., Marine Habitat Mapping Technology for Alaska: Alaska Sea Grant College Program, University of Alaska Fairbanks, doi:10.4027/mhmta.2008.04.

Carter, L., Milliman, J.D., Talling, P.J., Gavey, R., and Wynn, R.B., 2012, Near-synchronous and delayed initiation of long run-out submarine sediment flows from a record-breaking river flood, offshore Taiwan: Geophysical Research Letters, v. 39, L12603, doi:10.1029/2012GL051172.

Goldfinger, C., et al., 2012, Turbidite Event History: Methods and Implications for Holocene Paleoseismicity of the Cascadia Subduction Zone: U.S. Geological Survey Professional Paper 1661-F, Reston, Virginia, U.S. Geological Survey, $184 \mathrm{p}$.

Lamb, M.P., Parsons, J.D., Mullenbach, B.L., Finlayson, D.P., Orange, D., and Nittrouer, C., 2008, Evidence for superelevation, channel incision and formation of cyclic steps by turbidity currents in Eel Canyon, California: Geological Society of America Bulletin, v. 120, p. 463-475, doi:10.1130/B26184.1.

Lamb, M.P., and Mohrig, D., 2009, Do hyperpycnalflow deposits record river-flood dynamics?: Geology, v. 37, p. 1067-1070, doi:10.1130/G30286A.1

Liu, J.T., Wang, Y.-H., Yang, R.J., Hsu, R.T., Kao, S.-J., Lin, H.-L., and Kuo, F.H., 2012, Cycloneinduced hyperpycnal turbidity currents in a submarine canyon: Journal of Geophysical Research, v. 117, C04033, doi:10.1029/2011JC007630.

Mulder, T., and Syvitski, J.P.M., 1995, Turbidity currents generated at river mouths during exceptional discharges to the world oceans: The Journal of Geology, v. 103, p. 285-299, doi:10.1086 1629747.

Mulder, T., Migeon, S., Savoye, B., and Jouanneau, J.-M., 2001, Twentieth century floods recorded in the deep Mediterranean sediments: Geology, v. 29 , p. 1011-1014, doi:10.1130/0091-7613 (2001)029<1011:TCFRIT>2.0.CO;2.

Mulder, T., Syvitski, J.P.M., Migeon, S., Faugon, J.-C., and Savoye, B., 2003, Marine hyperpycnal flows: Initiation, behavior and related deposits. A review: Marine and Petroleum
Geology, v. 20, p. 861-882, doi:10.1016/j .marpetgeo.2003.01.003.

Mullenbach, B.L., and Nittrouer, C.A., 2006, Decadal record of sediment export to the deep sea via Eel Canyon: Continental Shelf Research, v. 26, p. 2157-2177, doi:10.1016/j.csr.2006.07.019.

Nittrouer, C.A., 1999, STRATAFORM: Overview of its design and synthesis of its results: Marine Geology, v. 154 , p. 3-12, doi:10.1016/S0025 -3227(98)00128-5.

Paull, C.K., Caress, D.W., Lundsten, E., Gwiazda, R., Anderson, K., McGann, M., Conrad, J., Edwards, B.D., and Sumner, E., 2013, Anatomy of La Jolla Submarine Canyon system; Offshore southern California: Marine Geology, v. 335, p. 16-34, doi:10.1016/j.margeo.2012.10.003.

Piper, D.J.W., and Normark, W.R., 2009, Processes that initiate turbidity currents and their influence on turbidites: A marine geology perspective: Journal of Sedimentary Research, v. 79, p. 347-362, doi:10.2110/jsr.2009.046.

Puig, P., Ogston, A.S., Mullenbach, B.L., Nittrouer, C.A., Parsons, J.D., and Sternberg, R.W., 2004, Storm-induced sediment gravity flows at the head of the Eel submarine canyon, northern California margin: Journal of Geophysical Research, v. 109, C03019, doi:10.1029/2003JC001918.

Puig, P., Palnanques, A., and Martín, J., 2013, Contemporary sediment-transport processes in submarine canyons: Annual Reviews of Marine Science, v. 6, p. 5.1-5.25.

Romans, B.W., Normark, W.R., McGann, M.M., Covault, J.A., and Graham, S.A., 2009, Coarsegrained sediment delivery and distribution in the Holocene Santa Monica Basin, California: Implications for evaluating source-to-sink flux at millennial time scales: Geological Society of America Bulletin, v. 121, p. 1394-1408, doi: 10.1130/B26393.1.

Smith, D.E., Harrison, S., Firth, C.R., and Jordan, J.T., 2011, The early Holocene sea level rise: Quaternary Science Reviews, v. 30, p. 18461860, doi:10.1016/j.quascirev.2011.04.019.

Sumner, E.J., Siti, M.I., McNeill, L.C., Talling, P.J., Henstock, T.J., Wynn, R.B., Djajadihardja, Y.S., and Haryadi Permana, H., 2013, Can turbidites be used to reconstruct a paleoearthquake record for the central Sumatran margin?: Geology, v. 41, p. 763-766, doi:10.1130 /G34298.1.

Talling, P., 2014, On the triggers, resulting flow types and frequencies of subaqueous sediment density flows in different settings: Marine Geology, doi:10.1016/j.margeo.2014.02.006.

Warrick, J.A., 2014, Eel River margin source-to-sink sediment budgets: Revisited: Marine Geology, doi:10.1016/j.margeo.2014.03.008.

Manuscript received 11 April 2014

Revised manuscript received 16 July 2014

Manuscript accepted 17 July 2014

Printed in USA 